\title{
ANALISIS KEMAMPUAN PEMECAHAN MASALAH PADA SOAL CERITA MATEMATIKA BERDASARKAN TEORI POLYA DITINJAU DARI ADVERSITY QUOTIENT
}

\author{
Novita Nurul Aini' ${ }^{1}$ Mohammad Mukhlis ${ }^{2}$ \\ ${ }^{1}$ Program Studi Tadris Matematika Institut Agama Islam Negeri Jember \\ 2Institut Agama Islam Negeri Jember, Indonesia \\ novitaafandi87@gmail.com
}

\begin{abstract}
:
One of the studen learning goals mathematics is mathematical reasoning for outcomes training student to solve the problems. One of the problems faced by students is word questions. There are several students responses in dealing with word question which is known as Adversity Quotient. This research aims to describe the students' problem solving skills in system of three-variable linear equations subject based on Polya's theory in terms of Adversity Quotient. This is a qualitative descriptive research with three subjects of students class X IPA 1 SMAN Arjasa Jember, there are one climber student, one camper student and one quitter student. These subjects took purposive sampling with consideration according to the results of questionnaire scores that meet each of the criteria of Adversity Quotient. Data collection techniques used were questionnaires, tests, interviews and observations. The validity test used is technical triangulation. Data analyzed through data condensation, data presentation and conclusion drawing. The results showed that student with the type of climber was able to meet all the indicators of problem solving in the problem of the word questions which included indicators of understanding the problem, planning the solution, carrying out the plan of solving and re-checking. Camper type student met all indicators of problem solving except at the re-checking stage. Quitter type student in completing word questions met the stage of understanding the problem and planning the solution, while the stage of carrying out the plan and re-checking is not fulfilled by the quitter student.
\end{abstract}

Keywords: Problem-solving, Polya's Theory, Adversity Quotient

\section{PENDAHULUAN}

Matematika adalah salah satu mata pelajaran yang penting bagi pendidikan khususnya di Indonesia. Hannell dalam Tok (2013) mengemukakan terkait pentingnya matematika dan menyatakan bahwa "mathematics is very important matter throughout human life. Today's pupils will all need mathematics when they leave school and get a job. Without an understanding of mathematics, they will be disadvantaged throughout their lives". Matematika tidaklah kongkrit, melainkan ilmu pengetahuan abstrak yang berguna bagi kehidupan sehari-hari. Tujuan matematika menurut Erviana (2019) agar siswa memiliki sikap rasa ingin tahu, perhatian, pantang menyerah, dan minat dalam mempelajari matematika serta sikap ulet dan percaya diri dalam pemecahan masalah. National Council of Teachers of Mathematics (NCTM, 2000; Anggraena, 2019) juga menyatakan bahwa tujuan pembelajaran matematika yaitu: (1) belajar untuk berkomunikasi (mathematical communication); (2) belajar untuk bernalar (mathematical reasoning); (3) belajar untuk memecahkan masalah (mathematical 
problem solving); (4) belajar untuk mengaitkan ide (mathematical connections); (5) pembentukan sikap positif terhadap matematika (positive attitudes toward mathematics). Dari pendapat di atas, dapat diketahui bahwa salah satu tujuan pembelajaran matematika adalah melatih siswa dalam memecahkan masalah.

Menurut Tohir (2019) masalah matematika maerupakan suatu masalah yang membutuhkan teknik tertentu untuk memecahkannya baik berupa soal rutin maupun non rutin. Menurut Hendriana \& Soemarmo (2014) mengatakan bahwa suatu soal dapat dikatakan sebagai masalah hanya jika seseorang tidak mempunyai aturan/hukum tertentu yang segera dapat dipergunakan untuk menemukan jawaban dari pertanyaan tersebut. Pemecahan masalah merupakan kunci yang penting sebagaimana dijelaskan oleh Annizar, Jakaria, Mukhlis, \& Apriyono (2020) bahwa problem solving is an important key when dealing with problems in everyday life that are related or not related to math. Terdapat beberapa pakar yang menaruh perhatian terhadap pemecahan masalah, diantaranya Gagne, John Dewey dan Polya. Menurut Gagne (Ruseffendi, 2005) mengatakan bahwa pemecahan masalah adalah tipe belajar yang tingkatnya paling tinggi dan kompleks dibandingkan dengan tipe belajar lainnya. Menurutnya langkah dalam pemecahan masalah terdiri dari menyajikan masalah dalam bentuk yang lebih jelas, menyatakan masalah ke bentuk yang operasional, menyusun hipotesis, mengetes hipotesis dan memeriksa hasil. Sedangkan menurut John Dewey dalam Fathurrahman, Permanasari, \& Siswaningsih (2016) pemecahan masalah adalah pemecahan atas sesuatu yang diragukan atau sesuatu yang belum pasti. Langkah dalam penyelesaian masalah menurut Dewey terdiri atas merumuskan masalah, menelaah masalah, merumuskan hipotesis, mengumpulkan data, menguji hipotesis dan menentukan pilihan penyelesaian. Adapun menurut Polya dalam Umar (2016) pemecahan masalah adalah suatu usaha mencari jalan keluar dari suatu kesulitan guna mencapai suatu tujuan yang tidak segera dapat dicapai, Polya merinci langkah-langkah pemecahan masalah meliputi memahami masalah, merencanakan atau merancang strategi pemecahan masalah, melaksanakan perencanaan, dan memeriksa kembali kebenaran hasil atau solusi.

Masalah yang dihadapi siswa salah satunya berupa soal cerita. Menurut Rosyidi (2005) soal cerita merupakan soal yang disajikan dalam bentuk cerita yang berkaitan dengan kenyataan yang ada di lingkungan siswa. Menurut Maswar (2019) mengatakan bahwa memberikan cerita-cerita matematis pada siswa dapat menarik perhatian dan merangsang otak mereka sehingga bekerja dengan baik, karena dengan mendengarkan cerita, siswa akan merasa senang sekaligus menyerap nilai-nilai/hikmah inspiratif dari cerita-cerita itu. Lebih lanjut Rosyidi (2005) mengatakan bahwa langkah-langkah yang harus ditempuh dalam menyelesaikan soal cerita yaitu: (1) membaca soal; (2) menentukan apa yang diketahui dan yang ditanyakan; (3) membuat model matematika; (4) melakukan perhitungan dan (5) menulis jawaban akhir dengan tepat. Langkahlangkah tersebut teringkas dalam langkah pemecahan Polya. Untuk itu, langkah-langkah pemecahan masalah yang digunakan dalam penelitian ini adalah langkah-langkah pemecahan masalah menurut Polya. Menurut Lestanti, Isnarto, \& Supriyono (2016) mengatakan bahwa langkah pemecahan Polya dapat dianggap sebagai langkah-langkah pemecahan masalah yang mudah dipahami dan banyak digunakan dalam kurikulum matematika di seluruh dunia. Penggunaan langkah-langkah pemecahan masalah Polya, diharapkan siswa dapat lebih runtut dan terstruktur dalam memecahkan masalah matematika. 
Menurut Hendriana \& Soemarmo (2014) pada tahap memahami masalah, yang dimaksud memahami disini adalah mengerti masalah dan melihat apa yang dikehendaki. Cara memahami suatu masalah diantaranya masalah harus dibaca berulang-ulang agar dapat dipahami kata demi kata, kalimat demi kalimat, menentukan/ mengidentifikasi apa yang diketahui dari masalah, menentukan/ mengidentifikasi apa yang ditanyakan/ dikehendaki dari masalah, mengabaikan hal-hal yang tidak relevan dengan masalah, sebaiknya tidak menambah hal-hal yang tidak ada agar tidak menimbulkan masalah yang berbeda dengan masalah yang seharusnya diselesaikan. Tahap memahami masalah ditandai dengan: (1) mengetahui apa yang diketahui dan ditanyakan, (2) menuliskan atau menjelaskannya dengan bahasa sendiri, (3) menghubungkannya dengan masalah lain serupa, dan (4) fokus pada bagian terpenting masalah tersebut. Pada tahap merencanakan strategi pemecahan masalah, yakni melihat bagaimana soal dihubungkan dan bagaimana ketidakjelasan dihubungkan dengan data agar memperoleh ide membuat rencana pemecahan masalah. Dalam menyusun perencanaan pemecahan masalah, dibutuhkan suatu strategi pemecahan masalah. Tahap ini ditandai dengan: (1) membuat atau menjelaskan rencana dengan bahasanya sendiri, (2) membuat model matematika, (3) mensketsa diagram, (4) menyederhanakan masalah, (5) menemukan rumus, (6) mengembangkan model matematika, (7) membuat simulasi, dan (8) mengurutkan data. Pada tahap melaksanakan pemecahan masalah, ditandai dengan adanya realisasi dari rencana penyelesaian berupa perhitungan. Setelah rencana penyelesaian dibuat, pelaksanaan rencana tersebut dilaksanakan sesuai perhitungan sebagaimana biasanya. Pada tahap mereview kembali pemecahan masalah, dilakukan dengan cara mengecek hasil, menginterpretasi jawaban yang diperoleh, meninjau kembali apakah ada cara lain yang dapat digunakan untuk mendapatkan penyelesaian yang sama, dan meninjau kembali apakah ada penyelesaian lain sehingga dalam memecahkan masalah dituntut tidak cepat puas dari satu hasil penyelesain saja, tetapi perlu dikaji dengan beberapa penyelesaian. Tahap ini ditandai dengan: (1) memeriksa kembali perhitungan yang telah dikerjakan, (2) membuat kesimpulan dari jawaban yang diperoleh, dan (3) mencari atau memeriksa jawaban dengan cara lain.

Materi soal cerita dalam matematika salah satunya adalah materi Sistem Persamaan Linear Tiga Variabel (SPLTV). Pemecahan masalah pada soal cerita materi SPLTV, diperlukan usaha keras dalam mengatasi masalah atau kesulitan yang ada, hal tersebut dikenal dengan Adversity Quotient. Adversity Quotient merupakan kecerdasan atau kemampuan seseorang dalam mengubah, mengolah sebuah permasalahan atau kesulitan dan menjadikannya sebuah tantangan untuk diselesaikan. Stoltz (2000) mengelompokkan tingkatan daya tahan siswa dalam menghadapi masalah menjadi tiga tingkatan, yakni climber, camper dan quitter. Climber merupakan orang yang senantiasa terus berjuang mengatasi suatu masalah, camper adalah orang yang merasa puas pada pencapaian tertentu sedangkan quitter yaitu orang yang menyerah atau memilih mundur dalam menghadapi masalah. Adversity Quotient tersebut perlu diperhatikan guna mencapai kesuksesan pembelajaran, salah satunya untuk siswa SMA khususnya SMAN Arjasa Jember. Berdasarkan observasi awal yang dilakukan oleh peneliti, karakteristik siswa SMAN Arjasa Jember berbeda-beda dalam merespon kegiatan pembelajaran. Ketika peneliti memberikan latihan soal, terdapat siswa yang bersemangat menyelesaikannya hingga selesai. Beberapa siswa pula ada yang menghentikan pekerjaannya dan bergegas melakukan aktivitas lain, serta ada pula yang enggan untuk menuntaskannya. Respon yang diberikan itulah yang dikenal dengan Adversity Quotient. 
Penelitian yang dilakukan oleh Yuwono, Supanggih, \& Ferdiani (2018) dengan judul "Analisis Kemampuan Pemecahan Masalah Matematika dalam Menyelesaikan Soal Cerita Berdasarkan Prosedur Polya" menunjukkan beragamnya kemampuan siswa dalam menyelesaikan soal cerita berdasarkan prosedur Polya. Akan tetapi Yuwono tidak meninjau subjek dari segi apapun. Mengetahui berperannya Adversity Quotient dalam mencapai kesuksesan belajar, maka peneliti tertarik untuk melibatkannya dalam penelitian ini. Berdasarkan uraian di atas, maka peneliti tertarik untuk melakukan penelitian dengan judul "Analisis Kemampuan Pemecahan Masalah Siswa pada Soal Cerita Matematika Berdasarkan Adversity Quotient". Adapun tujuan dalam penelitian ini adalah untuk mendeskripsikan kemampuan pemecahan masalah siswa pada soal cerita materi SPLTV berdasarkan teori Polya ditinjau dari Adversity Quotient.

\section{METODE PENELITIAN}

Pendekatan dalam penelitian ini adalah pendekatan kualitatif dengan jenis deskriptif, artinya penelitian ini bertujuan untuk mendeskripsikan gambaran yang jelas dan terperinci mengenai kemampuan pemecahan masalah matematika pada soal cerita materi Sistem Persamaan Linear Tiga Variabel berdasarkan teori Polya ditinjau dari Adversity Quotient. Siswa penelitian ini adalah tiga siswa kelas X IPA 1 SMAN Arjasa Jember, terdiri dari satu siswa bertipe climber, satu siswa bertipe camper dan satu siswa bertipe quitter. Pemilihan Siswa tersebut dilakukan secara purposive sampling, sesuai skor angket Adversity Response Profile (ARP) yang diperoleh. Data dikumpulkan dengan memberikan angket Adversity Response Profile yang diadaptasi dari buku Paul G. Stoltz guna menemukan Siswa penelitian, tes pemecahan masalah berupa dua buah soal essay, wawancara semi terstruktur dan observasi terbuka untuk mengetahui kemampuan masing-masing siswa. Sebelum digunakan dalam mengambil data, terlebih dahulu soal tes pemecahan masalah, angket, serta pedoman wawancara divalidasi oleh empat validator ahli yang terdiri dari tiga dosen Tadris Matematika IAIN Jember dan satu guru matematika wajib SMAN Arjasa Jember. Teknik analisis data yang digunakan adalah model dari Huberman, Miles, \& Saldana (2014) yang terdiri dari tiga tahap yakni kondensasi data, penyajian data dan penarikan kesimpulan. Validitas data dipastikan dengan triangulasi teknik, yakni dengan membandingkan data yang diperoleh dari hasil tes, wawancara dan observasi.

\section{HASIL DAN PEMBAHASAN}

Sebelum membahas terkait kemampuan masing-masing subjek penelitian, berikut disajikan soal yang digunakan dalam penelitian ini. Soal yang digunakan merupakan soal cerita materi SPLTV. Kedua soal tersebut dibuat langsung oleh peneliti yang kemudian divalidasi oleh empat validator serta telah diuji kevalidannya di lapangan. Berikut hasil validasi tersebut.

Tabel 1. Validitas Soal Cerita SPLTV

\begin{tabular}{|c|c|c|c|}
\hline No. & $\mathbf{r}_{\text {hitung }}$ & $\mathbf{r}_{\text {tabel }}$ & Keterangan \\
\hline $\mathbf{1}$ & 0,843 & 0,3961 & Valid \\
\hline $\mathbf{2}$ & 0,893 & 0,3961 & Valid \\
\hline
\end{tabular}




\section{Novita Nurul Aini \& Mohammad Mukhlis}

Berdasarkan tabel 1 diatas, maka untuk menghitung kevalidan, penulis membandingkan nilai $r_{\text {hitung }}$ dengan $r_{\text {tabel }}$. Nilai $r_{\text {tabel }}$ yang diperoleh adalah 0,3961. Menurut Amanda, Yanuar, \& Devianto (2019) jika nilai $r_{\text {hitung }}$ lebih besar daripada $r_{\text {tabel }}$ maka soal tersebut valid. Berdasarkan tabel di atas, kedua soal dinyatakan valid. Lebih lanjut menurut Amanda et al. (2019) mengatakan bahwa suatu instrumen dikatakan reliabel jika nilai Cronbach's Alpha lebih dari 0,6. Hasil uji reliabilitas menunjukkan nilai Cronbach's Alpha 0,669, lebih besar dari 0,6 sehingga soal tersebut reliabel. Berikut soal tes pemecahan yang telah valid dan digunakan dalam pengambilan data pada penelitian ini.

Tabel 2. Soal Tes Pemecahan Masalah

\begin{tabular}{ll}
\hline No & Soal \\
\hline Joko, Khozin dan Munir melakukan perjalanan ke alun-alunbeberapa daerah untuk \\
menyerahkan undangan ke beberapa temannya. Mereka berangkat bersama dan \\
dari tempat yang sama pula, yakni alun-alun Jember. Perjalanan mereka \\
ditunjukkan oleh maps berikut, beserta jarak tempuhnya yang terhitung dari alun- \\
alun Jember.
\end{tabular}

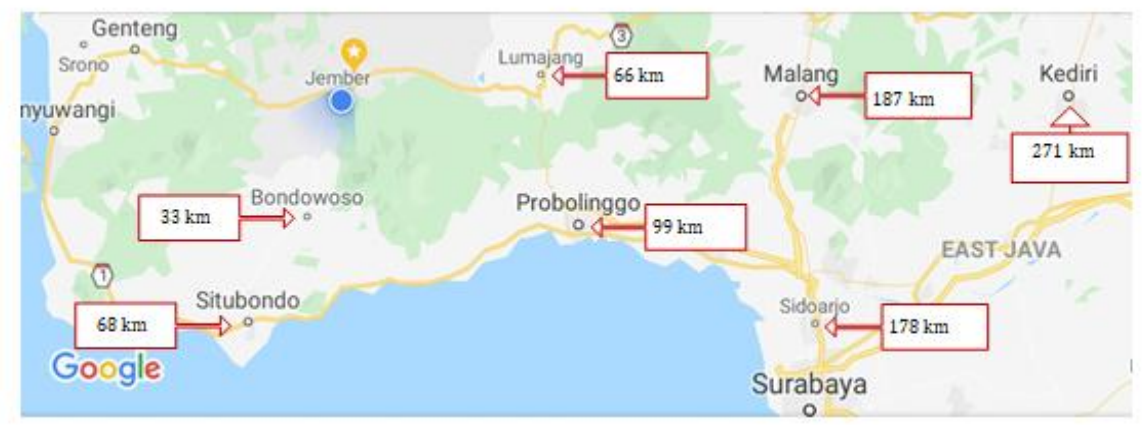

Sumber: Google Maps

Skala: $1: 1.000 .000$

Gambar 1. Peta Jawa Timur

Jumlah jarak tempuh Joko, Khozin dan Munir adalah $464 \mathrm{~km}$. Jarak tempuh Joko $9 \mathrm{~km}$ lebih jauh dibandingkan jarak tempuh Munir. Sedangkan empat kali dari jarak tempuh Khozin dikurangi jarak tempuh Joko dan Munir adalah $31 \mathrm{~km}$. Hitunglah berapa kilometer jarak tempuh dari Joko, Munir serta Khozin, lalu tentukanlah daerah tujuan mereka masing-masing berdasarkan jarak yang tersedia pada maps di atas!

Dani, David dan Rian adalah tiga sejoli yang merupakan siswa SMAN Arjasa Jember yang rumahnya tidak begitu dekat. Pada malam Minggu ini, mereka sepakat untuk membeli makanan di Mie Gacoan yang dipesan melalui Grab Food dari rumahnya masing-masing. Mereka memilih membeli Mie Gacoan sebab pada hari ini sedang ada promo bebas pajak. Dani membeli dua porsi mie setan level 2,

2 sebuah siomay dan sebuah es tuyul dengan harga keseluruhan $R p$ 50.000. David membeli seporsi mie setan level 2, tiga buah siomay dan sebuah es tuyul dengan harga keseluruhan $R p$ 64.000. Sedangkan Rian membeli seporsi mie setan level 2, sebuah siomay dan sebuah es tuyul dengan harga keseluruhan $R p$ 50.000. Semua harga keseluruhan tersebut sudah termasuk ongkos kirim. Ongkos kirim tersebut ditunjukkan oleh timeline GrabFood berikut. 


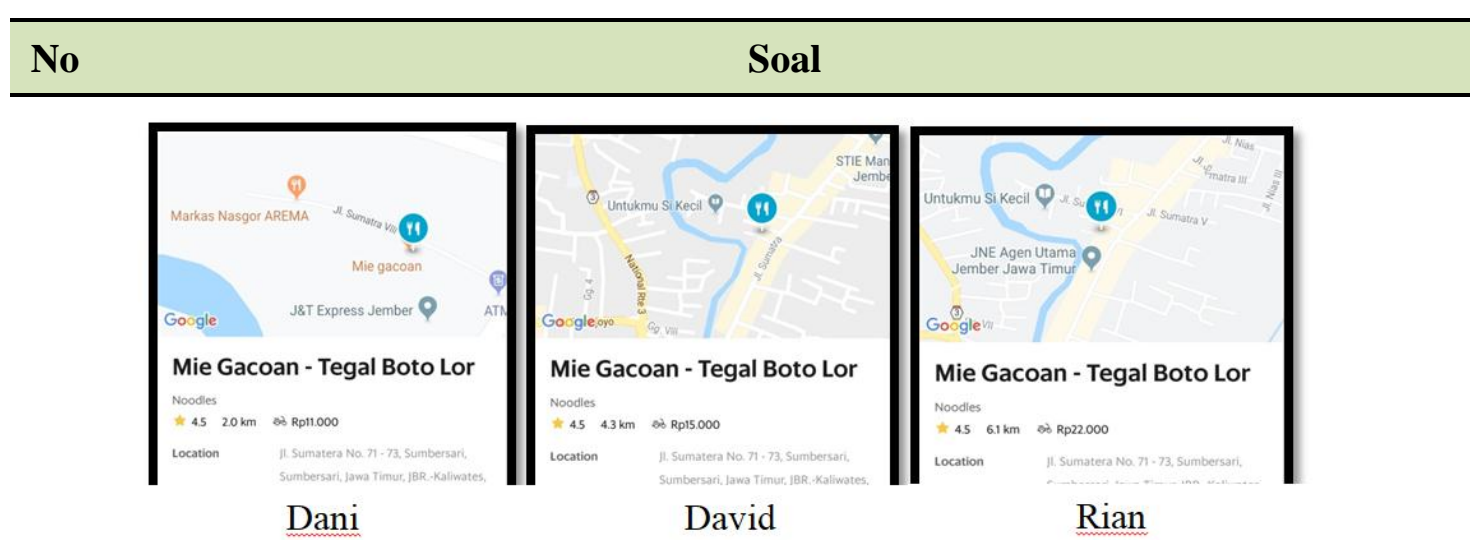

\section{Gambar 2. Timeline Grabfood}

Jika Tari, salah satu teman Dani saat ini berada di Mie Gacoan Jember dan akan membeli 5 porsi mie setan level 2, dua buah siomay dan tiga gelas es tuyul, maka berapakah harga keseluruhan yang harus dibayarkan Tari?

\section{Kemampuan Pemecahan Masalah Siswa Climber}

\section{a. Soal Nomor 1}

Indikator memahami masalah dipenuhi oleh siswa climber untuk soal pertama, hal tersebut dapat dilihat dari hasil pekerjaan siswa berikut.

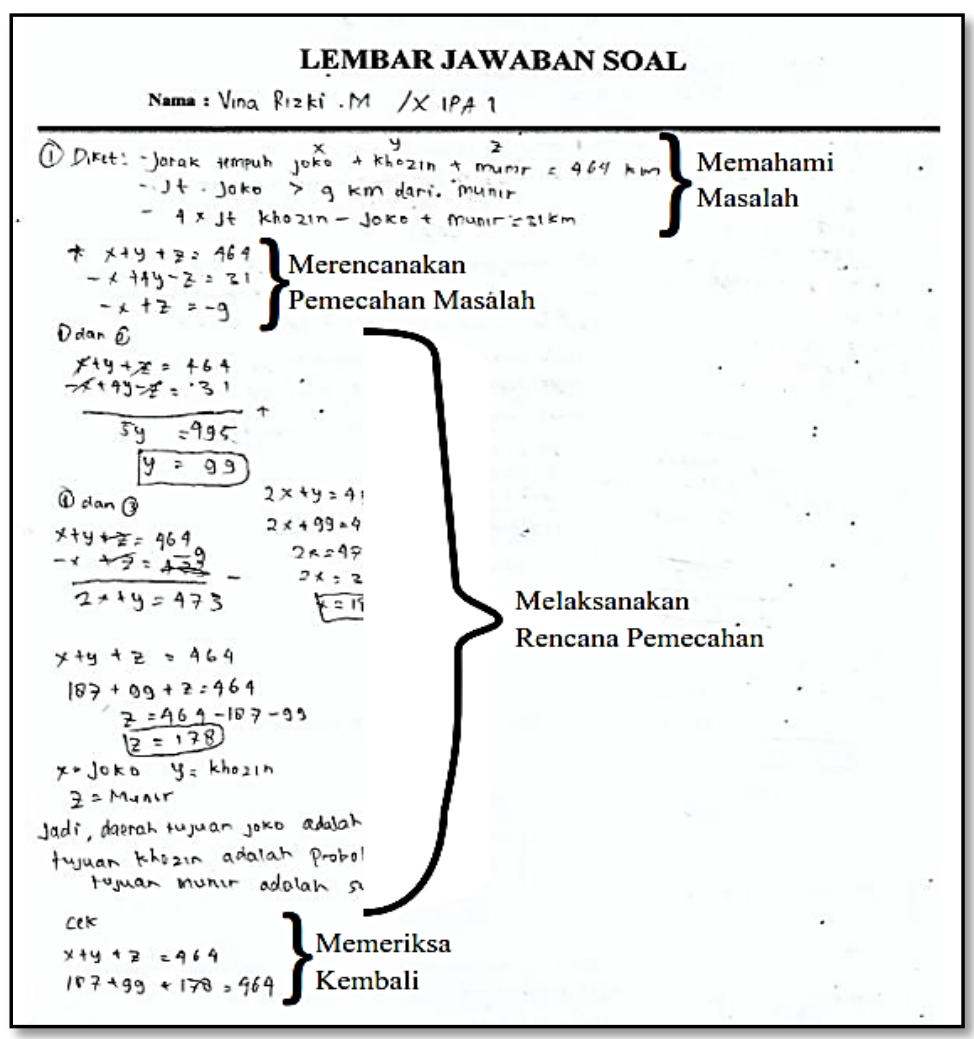

Gambar 3. Penyelesaian Climber Soal Nomor 1 


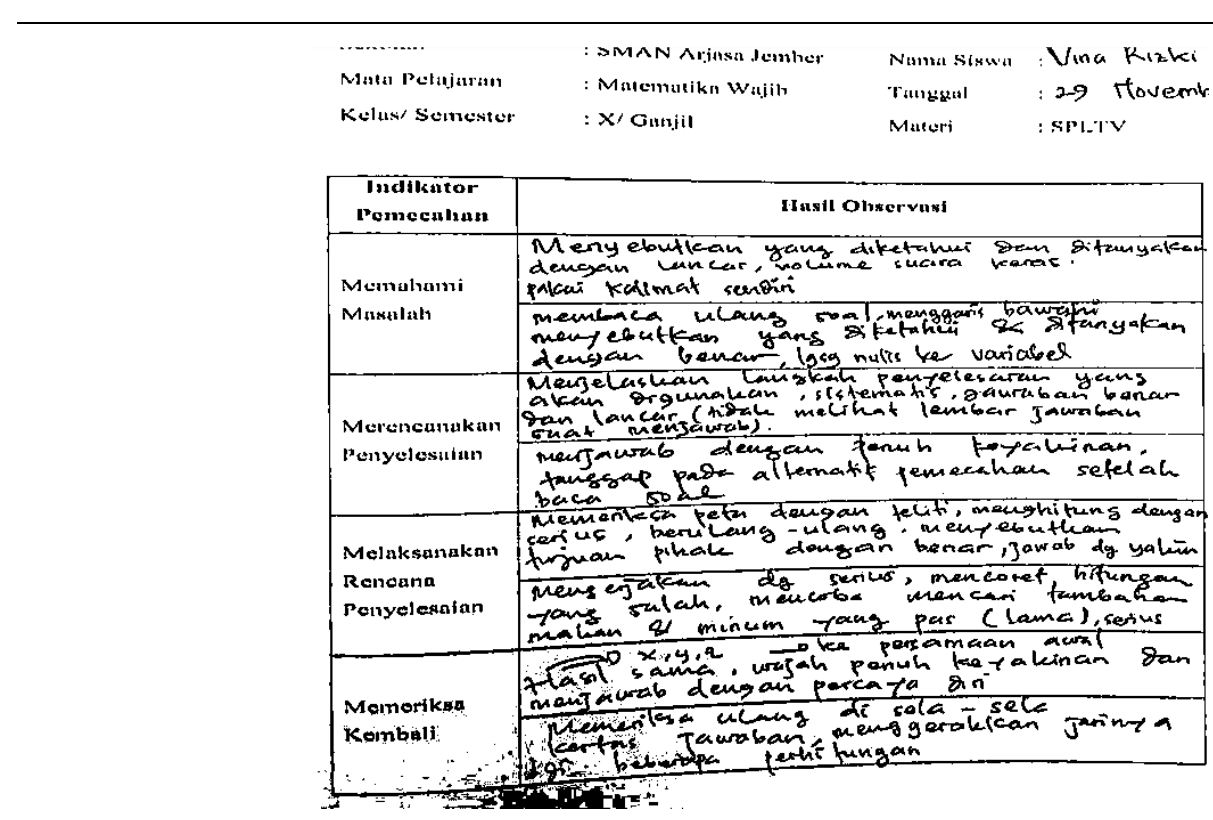

Gambar 4. Hasil Observasi Siswa Climber

Pada indikator memahami masalah, siswa dapat memahami masalah dengan baik. Gambar 3 menunjukkan bahwa siswa menuliskan secara rinci dan benar mengenai apa yang diketahui dalam soal, yang terdiri atas tiga poin informasi. Siswa tidak menuliskan apa yang ditanyakan soal. Berikut hasil wawancara dengan siswa climber.

Peneliti : "Sudah baca soalnya?"

Siswa 1 : "Sudah bu.."

Peneliti : "Paham maksud soalnya?

Siswa 1 : "Paham" (dengan nada yakin)

Peneliti : "Gimana maksudnya?

Siswa 1 : "Jadi kan jarak dari tempuhnya Joko ditambah Khozin ditambah Munir 464 km. Terus jarak tempuh Joko $9 \mathrm{~km}$ lebih jauh dari Munir. Berarti Munir ditambah $9 \mathrm{~km}$ sama dengan Joko. Terus empat kali dari jarak tempuh Khozin dikurangi jarak tempuh Joko dan Munir itu 31.”

Peneliti : "Oke berarti paham ya, yang ditanya apa?"

Siswa 1 : "Yang ditanya kan jarak tempuh masing-masing itu"

Peneliti : "Tadi ngisi apa ditanyanya?"

Siswa 1 : "Nilai $x, y$ dan $z$ bu"

Peneliti : "Emang $x, y, z$ itu apa"

Siswa 1 : "Itu bu sudah saya kasih kode diatasnya diketahui. Joko $x$, Khozin y, Munir z. Biar gak terlalu panjang bu."

Berdasarkan hasil wawancara yang dilakukan, siswa dengan sangat yakin dan lancar dapat menyebutkan apa yang diketahui dan dapat menyatakan kembali apa yang ditanyakan dalam soal menggunakan bahasanya sendiri. Berdasarkan observasi, siswa menjelaskan apa yang diketahui dengan sangat yakin dan lancar. Sehingga hal ini berarti siswa memenuhi indikator memahami masalah. 
Indikator kedua yakni merencanakan pemecahan masalah. Berdasarkan Gambar 3, siswa dapat menuliskan permisalan ke bentuk $x, y$ dan $z$. Kemudian siswa juga membuat model matematika berupa sistem persamaan linear tiga variabel dengan benar. Berikut hasil wawancara dengan siswa climber.

Peneliti : "Oiya oke, terus gimana ngerjakannya?"

Siswa 1 : "Saya misalkan Joko itu x, Khozin itu y, Munir itu z. terus yang diketahui yang pertama kan $x+y+z=464$, terus yang diketahui yang kedua $z+9 \mathrm{~km}=x$, berarti $-x+z=-9$. Terus empat kali dari jarak tempuh Khozin dikurangi jarak tempuh Joko dan Munir itu berarti $4 y-(x+z)=$ 31 , jadi $4 y-x-z=31$. Terus itu dijadiin persamaan tiga variabel."

Peneliti : "Terus?"

Siswa 1 : "di eliminasi persamaan yang pertama dan kedua, nanti ketemu y nya ya bu"

Berdasarkan wawancara serta observasi yang dilakukan, siswa menyebutkan permodelan matematika yang dibuatnya dengan benar dan lancar. Hal ini menunjukkan bahwa siswa dapat merencanakan arah penyelesaian dan memenuhi indikator merencanakan pemecahan.

Indikator ketiga yaitu melaksanakan rencana penyelesaian. Indikator ini ditandai dengan adanya langkah penyelesaian soal. Berdasarkan Gambar 3, siswa menuliskan penyelesaian dengan tepat. Siswa melaksanakan proses sesuai dengan apa yang direncanakan sebelumnya yakni dengan menggunakan eliminasi dan substitusi. Setelah menemukan nilai dari $x, y, z$, siswa memeriksanya pada peta dengan teliti dan menentukan tempat tujuan masing-masing pihak dengan benar.

Peneliti : "Terus?"

Siswa 1 : "di eliminasi persamaan yang pertama dan kedua, nanti ketemu y nya ya bu"

Peneliti : "Terus?"

Siswa 1 : "kemudian yang 1 sama yang ketiga, sampe ketemu persamaan $2 x+y=$ 473, terus nanti $y$ nya dimasukkan ketemu hasilnya $\mathrm{x}$ itu 187 ". Terus kalo cari yang $z$ dimasukin persamaan $x+y+z=464$, Jadi $187+99+z=$ 464. Jadi hasilnya $z$ nya nanti 178 "

Peneliti : "Terus kalo uda ketemu $x, y, z$ nya diapakan?"

Siswa 1 : "nanti dicari di peta bu. Kan Joko dimisalkan $x$, Joko jarak tempuhnya itu yang 187 km, Jadi ke Malang."

Peneliti : "Terus?"

Siswa 1 : "Khozin kan 99, berarti ke Probolinngo, terus yang Munir ketemunya kan 178 jadi tujuannya ke Sidoarjo"

Berdasarkan wawancara tersebut, siswa menyebutkan dengan penuh keyakinan bahwa tujuan dari Joko adalah Malang, Khozin adalah Probolinggo dan Munir adalah Sidoarjo. Dapat disimpulkan bahwa siswa memenuhi tahap melaksanakan rencana pemecahan masalah dengan sangat baik.

Indikator terakhir yaitu memeriksa kembali. Berdasarkan Gambar 3, siswa memeriksa kembali jawaban yang diperolehnya dengan cara mensubstitusikan nilai $x, y, z$ ke salah satu persamaan dalam soal. 
Peneliti : "Terus?"

Siswa 1 : "di eliminasi persamaan yang pertama dan kedua, nanti ketemu y nya ya bu"

Peneliti : "Terus?"

Siswa 1 : "kemudian yang 1 sama yang ketiga, sampe ketemu persamaan $2 x+y=$ 473 , terus nanti $y$ nya dimasukkan ketemu hasilnya $\mathrm{x}$ itu 187 ". Terus kalo cari yang $z$ dimasukin persamaan $x+y+z=464$, Jadi $187+99+z=$ 464. Jadi hasilnya $z$ nya nanti 178 "

Peneliti : "Terus kalo uda ketemu $x, y, z$ nya diapakan?"

Siswa 1 : "nanti dicari di peta bu. Kan Joko dimisalkan x, Joko jarak tempuhnya itu yang 187 km, Jadi ke Malang."

Peneliti : "Terus?"

Siswa 1 : "Khozin kan 99, berarti ke Probolinggo, terus yang Munir ketemunya kan 178 jadi tujuannya ke Sidoarjo"

Berdasarkan wawancara tersebut terlihat bahwa siswa sudah benar-benar yakin dengan jawabannya karena telah memeriksanya di sela-sela bagian kosong kertasnya. Berdasarkan observasi, siswa mengerjakan soal dengan serius dan teliti, bahkan menghitung ulang dengan menggerakkan jemarinya ke penyelesaian yang telah dikerjakan sebelumnya. Berdasarkan hal tersebut, siswa memenuhi indikator memeriksa kembali.

\section{b. Soal Nomor 2}

Jawaban siswa pada soal nomor 2 dapat dilihat pada gambar berikut.

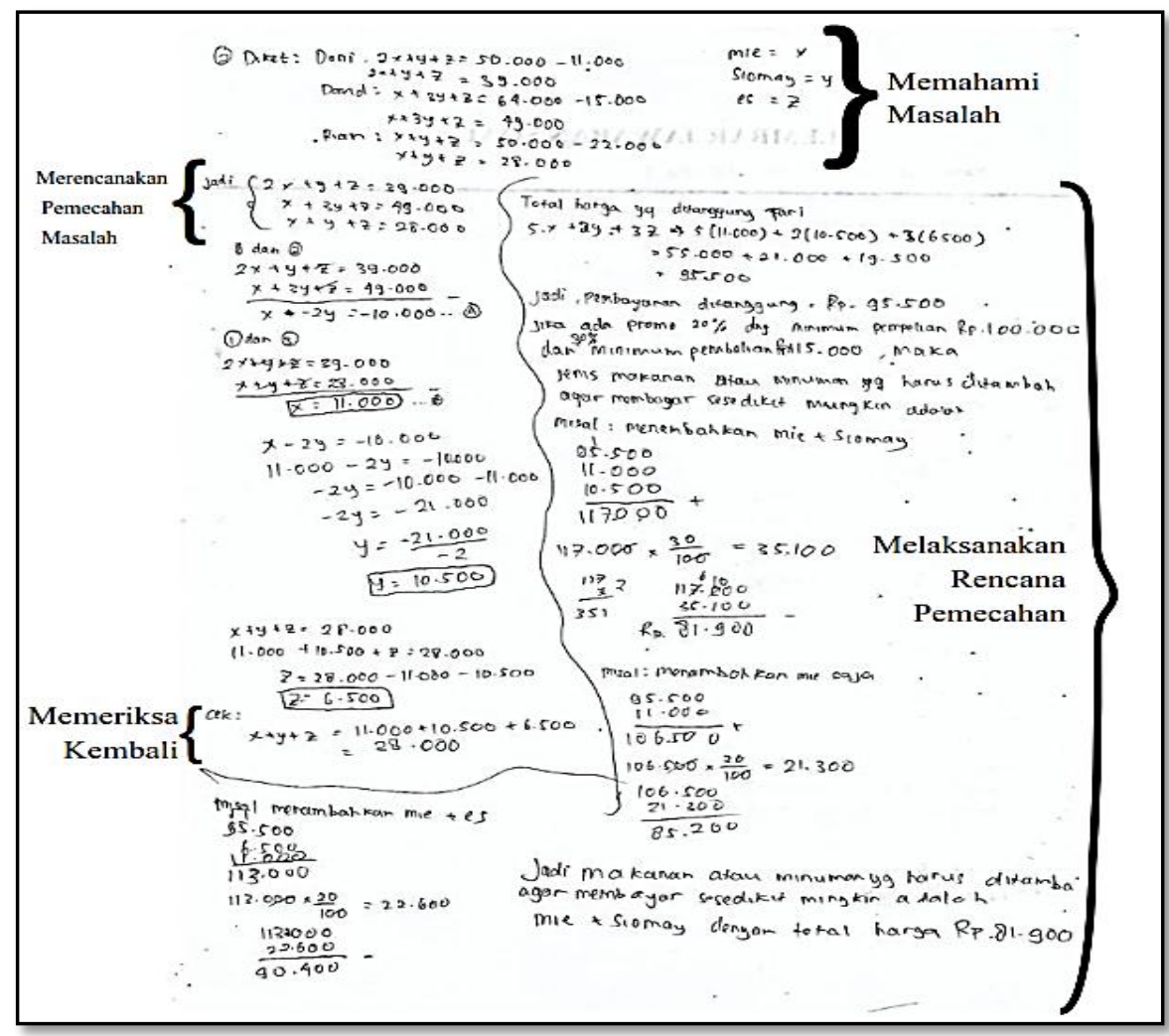

Gambar 5. Penyelesaian Climber Soal nomor 2 
Berdasarkan Gambar 5, siswa climber menuliskan apa yang diketahui soal. Siswa tersebut menuliskan hal tersebut dalam kalimat matematika atau variabel yakni menggunakan $x, y$ serta $z$. Siswa climber ini tidak menuliskan apa yang ditanyakan di awal pemecahan. Ia langsung menuliskan di akhir ketika hendak mengambil sebuah kesimpulan.

Peneliti : "Sudah dibaca soal nomor 2?"

Siswa 1 : "Sudah Bu"

Peneliti : Gimana, paham sama permasalahan yang ada di nomor 2?"

Siswa 1 : "Paham insyaallah"

Peneliti :"Coba, apa yang dipahami?"

Siswa 1 : "Ada 4 anak beli-beli di Mie Gacoan, yang tiga belinya delivery, yang satu langsung datang ke tokonya."

Peneliti : "Iya, apa aja yang dapat diketahui dari soal?"

Siswa 1 : "Dani beli 2 mie setan, 1 siomay sama 1 es tuyul harganya 50.000, kan mesennya pakai Grab berarti masih dikurangi ongkos kirimnya 11.000, jadi 39.000. terus David beli 1 mie, 3 siomay dan 1 es tuyul harga totalnya 64.000 dikurangi 15.000 jadi $49.000 "$

Peneliti : Iya, terus?"

Siswa 1 : "Terus punya Rian beli 1 mie setan, 1 siomay dan 1 es tuyul harganya 50.000 , ongkos kirimnya 22.000 jadi total belinya berarti $28.000 "$

Peneliti : "Tadi di pekerjaannya apa nulis persis seperti itu?"

Siswa 1 : "Maksudnya Bu? (diam sejenak), Oh nggak Bu, pake $x, y, z$ "

Peneliti : "Lho, $x, y, z$ itu apa emang?"

Siswa 1 : "Variabel Bu, x itu mie, y itu siomay dan z itu es?"

Peneliti : "Kenapa kok nulisnya dalam bentuk variabel?"

Siswa 1 : "Biar gak terlalu panjang $\mathrm{Bu}$, Biar cepet juga. Gak boleh ta bu kalau langsung?"

Peneliti :"Gak papa sih, oke terus apa yang ditanyakan soal?"

Siswa 1 : "Harga yang dibayar Tari kalau beli 5 mie setan, 2 siomay dan 3 es tuyul"

Berdasarkan hasil wawancara siswa menyebutkan apa yang diketahui serta yang ditanyakan dengan lancar menggunakan bahasanya sendiri dan ia dengan sengaja menuliskan langsung ke dalam variabel dengan maksud agar tidak terlalu panjang serta tidak memotong waktu pengerjaannya. Ketika menuliskan apa yang diketahui, siswa cukup teliti, karena ia memperhatikan ongkos kirim yang ada sehingga estimasi biaya yang dikeluarkan pada setiap persamaan sudah benar. Siswa climber tidak menuliskan apa yang ditanyakan, berdasarkan observasi, ia membaca soal berulang-ulang soal untuk menemukan informasi yang diketahui dan ditanyakan kemudian menggaris bawahi apa yang ditanyakan dalam soal. Berdasarkan hal tersebut, siswa climber memenuhi indikator memahami masalah dengan baik.

Setelah menuliskan apa yang diketahui, siswa climber menuliskan model matematika berupa persamaan ke bentuk yang lebih sederhana. Berdasarkan Gambar 5, terdapat tiga buah persamaan yang dituliskan diantaranya $2 x+y+z=39.000, x+$ 
$3 y+z=49.000$ dan $x+y+z=28.000$. Dibawah persamaan tersebut, tertuliskan

"lalu dieliminasi", artinya siswa memiliki gambaran atau rencana arah penyelesaian.

Peneliti :"Terus bagaimana adik bayangkan penyelesaiannya?"

Siswa 1 : "Pake cara SPLTV Bu"

Peneliti : "Coba jelaskan langkah-langkah ngerjakannya"

Siswa 1 : "Pertama kan tadi diketahui ya bu banyak, itu dibuat persamaan $\mathrm{Bu}$, mienya $x$, siomaynya $y$, esnya $z$. Jadinya nanti $2 x+y+z=39.000, x+3 y+z=$ 49.000, $x+y+z=28.000 "$

Peneliti : "Terus?"

Siswa 1 : "Dieliminasi persamaan 1 dan 2. Persamaan satunya kan $2 x+y+z=$ 39.000, terus persamaan duanya kan $x+3 y+z=49.000$. Kemudian dikurangi, ketemu hasilnya $x-2 y=-10.000$. Itu nanti jadi persamaan yang A. Terus eliminasi persamaan 1 dan 3. Persamaan $12 x+y+z=$ 39.000, persamaan $3 x+y+z=28.000$. Kemudian di eliminasi yang y sama $\mathrm{z}$ nya. Nanti ketemu nilai $\mathrm{x}$ nya yaitu 11.000 . Terus $\mathrm{x}$ ini dimasukkan ke persamaan yang A yaitu $x-2 y=-10.000$. Jadi $11.000-2 y=$ -10.000 , terus nanti ketemu hasilnya y yaitu 10.500.” Dst

Berdasarkan wawancara tersebut serta observasi yang dilakukan, siswa climber dapat memaparkan rencana penyelesaiannya menggunakan bahasanya sendiri dengan benar dan yakin. Jadi disimpulkan bahwa siswa climber memenuhi indikator merencanakan pemecahan masalah.

Pada indikator ketiga yakni melaksanakan rencana pemecahan, siswa menuliskan langkah-langkah penyelesaian. Langkah penyelesaian yang disajikan menggunakan eliminasi dan substitusi. Langkah yang dituliskan sistematis dan diselesaikan hingga siswa climber menemukan nilai $x, y$, dan $z$. Hal tersebut dapat dilihat pada Gambar 5. Akan tetapi siswa climber gagal dalam menemukan jenis makanan atau minuman yang harus ditambahkan agar membayar seminim mungkin. Ia mengerjakan dengan cara coba-coba dan menemukan hasil menambahkakn es dan siomay. Padahal terdapat pembayaran yang lebih minim yakni menambahkan es tuyul 3 buah.

Peneliti : "Terus diapakan?"

Siswa 1 : "Terus untuk cari z masukkan ke persamaan yang awal tadi itu, yang $x+y+$ $z=28.000$."

Peneliti : "Kenapa kok milih yang itu?"

Siswa 1 : "karena lebih gampang."

Peneliti : "Iya. Terus lanjutkan"

Siswa 1 : "x nya kan udah ketemu 11.000 , sama y nya 10.500 , jadi $11.000+10.500+$ $z=28000$. Nanti ketemu nilai $z$ yaitu 6.500"

Peneliti : "Terus?"

Siswa 1 : "Terus kan sudah ketemu nilai $x, y, z$ nya. Terus di soal ini ada Tari beli 5 mie setan yaitu $5 x$, terus 2 siomay yaitu 2 y dan es tuyul yaitu $3 z$. berapakah harga keseluruhan yang dibayarkan Tari? Berarti dimasukkan nilai yang telah didapatkan tadi ke persamaan yang barusan. Jadi $5 x$ berarti $5 \times 11.000$, terus 
ditambah $2 y$ yaitu $2 \times 10.500$, terus ditambah $3 z$, yaitu $3 \times 6500$. Nanti akan ketemu hasilnya yang harus dibayarkan Tari adalah $95.500 "$

Peneliti : Terus?"

Siswa 1 : "Terus, sudah"

Berdasarkan hasil wawancara dan observasi, siswa climber menjelaskan bahwa langkah yang dilakukannya adalah eliminasi persamaan 1 dan 2, 1 dan 3, A dan B hingga ditemukan nilai $x, y, z$ dan disubstitusikan pada apa yang ditanyakan. Lalu untuk mencari jenis makanan dilakukan pengecekan satu persatu. Namun siswa climber hanya dapat melakukan 3 pengecekan dengan alasan menganggap harga yang ditemukan sudah minim. Berdasarkan hasil wawancara dapat disimpulkan bahwa siswa climber memenuhi indikator melaksanakan rencana pemecahan masalah, akan tetapi masih kurang tepat.

Indikator yang keempat yakni memeriksa kembali. Berdasarkan Gambar 5, siswa climber dapat memenuhi indikator tersebut. Pemeriksaan siswa climber ditulis lebih kecil di sela-sela bagian kertas kosongnya. Selain itu, melalui wawancara berikut ia menjelaskan bahwa sudah melakukan pemeriksaan kembali.

Peneliti :"Yakin sudah benar?"

Siswa 1 : "Udah"

Peneliti : Bagaimana bisa yakin jika jawabannya sudah benar? Sudah dicek?"

Siswa 1 : "Sudah"

Peneliti : Mana?"

Siswa 1 : "Ini"”

Peneliti : "Gimana maksudnya ini?"

Siswa 1 : " $x, y, z$ nya disubstitusikan Bu. Kalo hasilnya sama berarti benar. Dan ini hasilnya sama $\mathrm{Bu}$, berarti benar.

Peneliti : "Oh gitu, Okay dek. Terimakasih ya, susah soalnya ta dek?"

Siswa 1 : "Lumayan Bu, tapi seru menantang"

Berdasarkan hasil wawancara didapat bahwa Siswa 1 melakukan pemeriksaan kembali terhadap jawaban yang diperoleh. Pemeriksaan yang dilakukan berupa substitusi pada salah satu persamaan yang diketahui. Terkait jenis makanan atau minuman yang ditambahkan, siswa climber sudah memeriksanya namun hasil yang didapat masih kurang tepat. Berdasarkan observasi, siswa climber kerap sekali melakukan pemeriksaan terhadap hasil hitungan yang didapatnya. Sehingga dapat diketahui bahwa siswa climber dapat memenuhi indikator memeriksa kembali meskipun kurang tepat.

Berdasarkan hasil tes, observasi dan wawancara pada siswa climber diperoleh hasil pemecahan sebagaimana terangkum dalam tabel berikut.

Tabel 3. Kemampuan Pemecahan Masalah Siswa Climber

\begin{tabular}{lcccc}
\hline Keterangan & Indikator 1 & Indikator 2 & Indikator 3 & Indikator 4 \\
\hline Nomor 1 & $\sqrt{ }$ & $\sqrt{ }$ & $\sqrt{ }$ & $\sqrt{ }$ \\
Nomor 2 & $\sqrt{ }$ & $\sqrt{ }$ & $\sqrt{ }$ & $\sqrt{ }$ \\
\hline
\end{tabular}

Alifmatika: Jurnal Pendidikan dan Pembelajaran Matematika, Juni 2020, Vol. 2, No. 1 


\section{Novita Nurul Aini \& Mohammad Mukhlis}

\section{Kemampuan Pemecahan Masalah Siswa Camper}

a. Soal Nomor 1

Penyelesaian siswa camper dan hasil observasi disajikan pada gambar berikut.

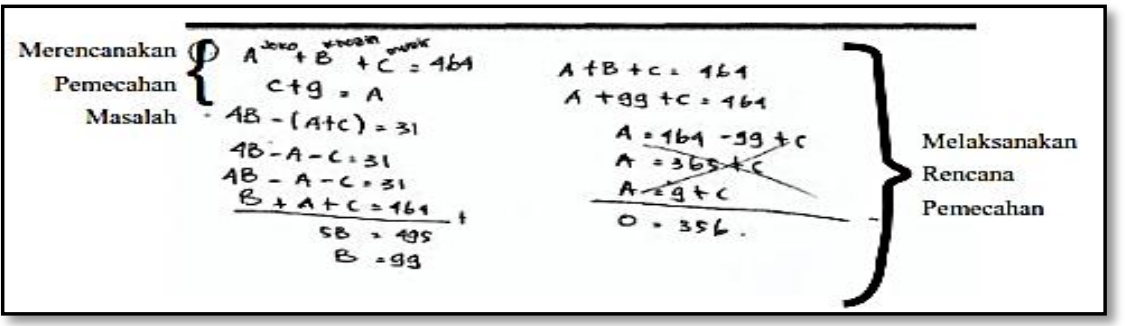

Gambar 6. Penyelesaian Camper Soal Nomor 1

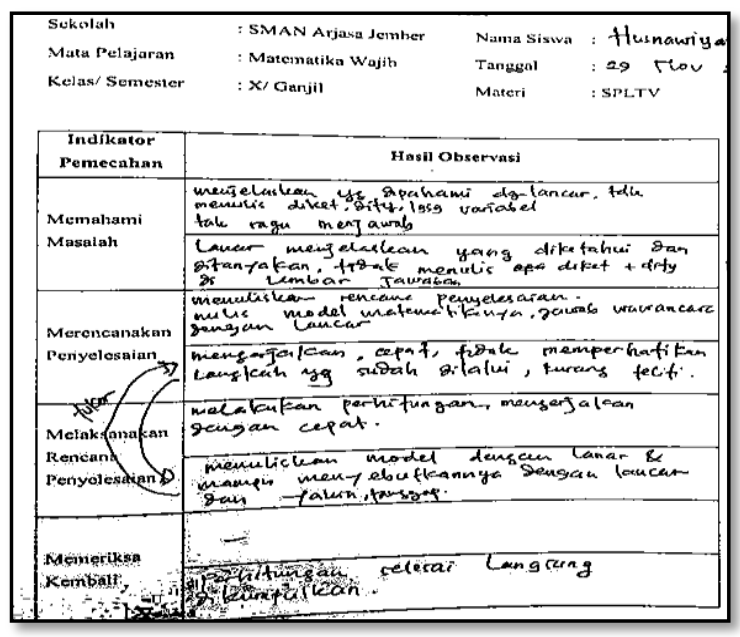

Gambar 7. Hasil Observasi Siswa Camper

Berdasarkan Gambar 6 tersebut di atas, menunjukkan bahwa siswa camper tidak dapat menuliskan informasi yang diketahui dengan detail. Namun menyatakannya ke variabel. Selain tidak dapat menuliskan apa yang diketahui, siswa camper juga tidak dapat menuliskan apa yang ditanyakan. Siswa camper dapat menyebutkan informasi yang diketahui serta ditanyakan. Siswa camper menggaris bawahi apa yang diketahui dan ditanyakan di soal yang diperoleh, jadi tidak menuliskan kembali dalam lembar jawabannya. Selanjutnya, untuk mendapatkan informasi kemampuan siswa didapat dari kutipan wawancara yang telah dilakukan berikut.

Peneliti :"... saya mau tanya yang nomor 1, gimana? Udah paham?"

Siswa 2 : "Sudah Bu"

Peneliti : "Gimana coba"

Siswa 2 : "Ada tiga anak yang meu nganter undangan ke temannya. Tapi daerahnya gak tau masih dimana. Itu yang dicari nanti. Jarak tempuh Joko, Khozin Munir $464 \mathrm{~km}$. Joko $9 \mathrm{~km}$ lebih jauh dibandingkan jarak tempuh Munir. Empat kalinya Khozin dikurangi jumlah Joko dan Munir itu 31.

Peneliti : Iya, dituliskan gak apa yang diketahui dan ditanyakan di lembar jawabannya tadi? 
Siswa 2 : "Nggak, harus ditulis tah Bu?"

Peneliti : "Iya nggak sih, gak ditulis gak apa-apa yang penting ngerti. Tapi akan lebih baik kalo ditulis."

Siswa 2 : "Oh iya $\mathrm{Bu}$, saya gak nulis $\mathrm{Bu}$, tapi saya garisi langsung di soalnya info yang penting-penting itu Bu. Seperti yang diketahui sama ditanya."

Berdasarkan hasil wawancara tersebut, siswa camper dapat menyebutkan informasi yang diketahui serta ditanyakan. Ia menggaris bawahi apa yang diketahui dan ditanyakan di soal yang diperoleh, jadi tidak menuliskan kembali dalam lembar jawabannya. Berdasarkan observasi yang dilakukan, siswa tersebut menyebutkan apa yang diketahui dengan bahasanya sendiri secara lancar dan tidak ada keraguan. Jadi siswa camper memenuhi indikator memahami masalah. Jadi siswa camper memenuhi indikator memahami masalah.

Pada indikator merencanakan pemecahan masalah, siswa camper dapat menuliskan model matematika yang terdiri dari beberapa persamaan. Persamaan yang dituliskanya sudah benar. Berikut kutipan wawancara dengan siswa camper.

Peneliti : "Oh gitu, terus langkah ngerjakannya gimana?"

Siswa 2 : "Dicari persamaan itunya dulu"

Peneliti : "Yang awal dibuat apa?"

Siswa 2 : "Apa Bu?"

Peneliti : "Ini, per....?"

Siswa 2 : "Permisalan."

Peneliti : "Iya gimana?"

Siswa 2 : "A + B + C = 464, C + $9=$ A, terus empat kali jarak tempuh Khozin.."

Peneliti : "Empat kali jarak tempuh Khozin berarti?"

Siswa 2 : "4B - $(A+C)$."

Peneliti : "Iya terus kalau sudah gitu diapakan?"

Siswa 2 : "Dicari satu-satu"

Peneliti : "Pakek apa?"

Siswa 2 : "Anu Bu"

Peneliti : "Apa?"

Siswa 2 : "Eliminasi danSubstitusi"

Peneliti : "Udah dicoba tadi?"

Siswa 2 : "Sudah Bu, ini. Di eliminasi nanti B nya ketemu"

Berdasarkan hasil wawancara tersebut dan observasi, menunjukkan bahwa siswa camper menjawab pertanyaan dengan tanggap dan mampu menyebutkan dengan lancar model matematika dengan membuatnya permisalan. Artinya, siswa camper dapat memenuhi indikator merencanakan pemecahan masalah.

Pada indikator melaksanakan rencana, siswa camper dapat menuliskan langkah penyelesaian sebagaimana pada Gambar 5. Namun langkah penyelesaian yang diberikan tidak tuntas. Siswa camper menemukan nilai dari B, sedangkan nilai A dan C serta lokasi masing-masing pihak tidak berhasil dituliskan. Dari hasil observasi, hal tersebut 
dikarenakan terdapat ketidaktelitian siswa camper dalam mengubah persamaan. Persamaan yang awalnya $A+99+C=464$ diubah menjadi $A=464-99+C$. Seharusnya persamaan tersebut menjadi $A=464-99-C$. Kemampuan siswa camper dapat diketahui dari kutipan wawancara berikut.

Peneliti : "Terus yang A dan C?"

Siswa 2 : "Gimana Bu eliminasinya

Peneliti : "Seperti biasanya itu dek"

Siswa 2 : "Gak bisa Bu"

Peneliti : "Gini dek, ini langkah awal sudah benar B nya ketemu 99. Nah setelah itu dieliminasi lagi B nya di substitusikan dulu kesini. Nanti dieliminasi sama yang $\mathrm{C}+9=\mathrm{A} . “$

Siswa 2 : "Gimana Bu"

Peneliti : "seperti tadi dek dijumlah atau dikurangkan"

Siswa 2 : "Gimana Bu belum ngerti"

Peneliti : "Inilo dek kan di substitusikan nilai B kesini, ini udah benar langkahmu. Cuma coba perhatikan lagi, C awalnya positif, pindah ruas kanan jadi?"

Siswa 2 : "Negatif"

Peneliti : "Punyamu jadi negatif nggak tadi? Ini.. (menunjukkan jawabannya)"

Siswa 2 : "Oh iya enggak Bu..

Peneliti : "Berarti tau kan salahnya dimana?

Siswa 2 : "Iya Bu,"

Peneliti : "Kenapa kok bisa salah?"

Siswa 2 : "Gak teliti Bu, sulit juga Bu angkanya besar.. ratusan"

Berdasarkan hasil wawancara, selain karena kurang teliti, siswa camper mengalami kesulitan untuk melanjutkan penyelesaiannya sebab angkanya cukup besar. Karena ada penyelesaian yang dituliskan, jadi siswa camper memenuhi indikator melaksanakan rencana pemecahan meskipun masih kurang.

Berdasarkan Gambar 6, siswa camper tidak dapat melakukan pemeriksaan kembali. Hal tersebut juga dapat diketahui dari kutipan wawancara berikut.

Peneliti : "Hemm, gak di cek ulang ta tadi pekerjaannya?"

Siswa 2 : "Enggak"

Peneliti : "Kenapa?"

Siswa 2 : "Gak tau Bu kenapa.. Gak biasa".

Peneliti : "Hmm, iyadah harus teliti loh yaa"

Siswa 2 : "Iya Bu"

Siswa camper tidak menuliskan pemeriksaan pada lembar jawabannya. Selain itu, berdasarkan wawancara dan observasi, siswa camper tidak melakukan pemeriksaan ulang terhadap apa yang sudah dikerjakannya. Sehingga dapat disimpulkan bahwa siswa camper tidak memenuhi indikator memeriksa kembali. 


\section{b. Soal Nomor 2}

Penyelesaian siswa camper pada soal nomor 2 disajikan pada gambar berikut.

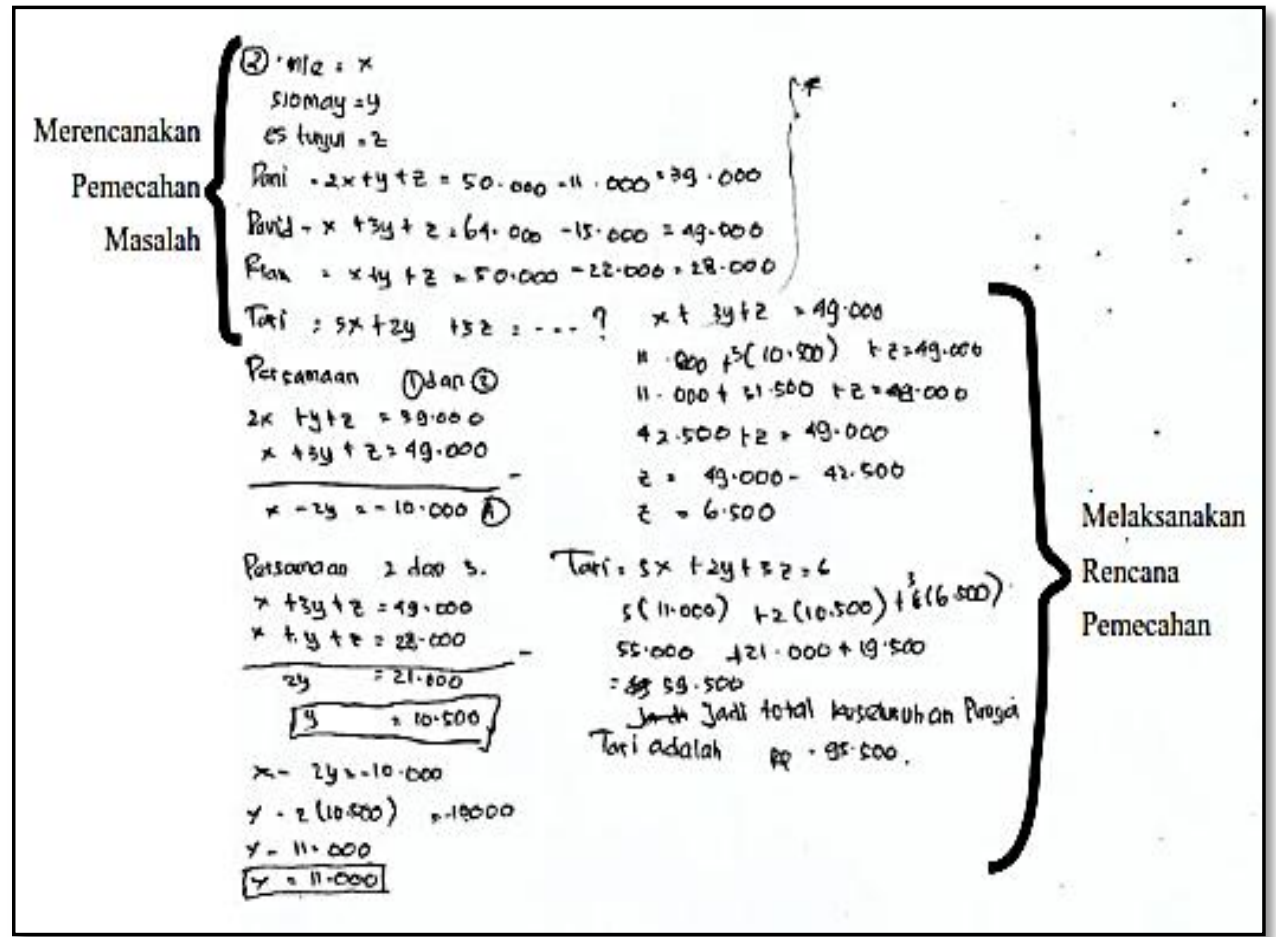

Gambar 8. Penyelesaian Camper Soal nomor 2

Berdasarkan Gambar 8, siswa camper menuliskan apa yang diketahui dari soal, namun informasi yang dituliskan dalam kalimat matematika, yakni menggunakan variabel. Siswa camper tidak menuliskan apa yang ditanyakan soal. Berikut kutipan wawancara dengan siswa camper.

Peneliti : "Paham sama maksud soalnya?"

Siswa 2 : "Paham Bu"

Peneliti : "Gimana maksud soalnya?"

Siswa 2 : "Dani beli 2 mie, satu siomay dan dua es harganya Rp 50.000 dikurangi ongkir 11.000. David beli 1 mie, tiga siomay dan segelas es harganya Rp 64.000 ongkirnya 15.000. Rian 1 mie, 1 siomay dan 1 es harganya Rp 50.000 ongkirnya 22.000

Peneliti : "Iya, terus yang ditanyakan?"

Siswa 2 : " $5 \mathrm{~A}+2 \mathrm{~B}+3 \mathrm{C}$ "

Peneliti : "Kok A,B,C? emang A, B, C itu apa?"

Siswa 2 : "A mienya, B siomay, C es. Kan gak papa bu?"

Peneliti : "Iya gak papa, yang diketahui gak ditulis juga ini ya.. sama dengan nomor 1" Siswa 2 : "Iya Bu, hehe. Gak biasa saya Bu"

Berdasarkan hasil wawancara, siswa camper memahami maksud dari soal. Berdasarkan hasil observasi, siswa menyebutkan dengan bahasanya sendiri terkait apa 
yang diketahui dan ditanyakan dari soal. Tidak dituliskan pada lembar jawaban sebab tidak terbiasa mengerjakan seperti itu. Siswa camper menjelaskan apa yang diketahui dan ditanyakan soal dengan yakin, artinya siswa camper sudah memenuhi indikator merencanakan pemecahan masalah.

Berdasarkan Gambar 8, siswa camper dapat menuliskan model matematika dari apa yang diketahui. Siswa camper menuliskan 3 buah persamaan yang ketiganya sudah benar.

Peneliti : "Terus gimana ngerjakannya dek?"

Siswa 2 : "Sama Bu kayak nomor 1, dari permisalan yang dibuat terus dieliminasi sama substitusi. Sampe ketemu nilai A, B sama C."

Peneliti : "Gak kesusahan buat model matematikanya? Udah ketemu tadi waktu ngerjakan?"

Siswa 2 : "Nggak Bu. Udah ketemu Bu, A nya 11.000, B nya 10.500 Cnya 6.500"

Peneliti : "Terus diapakan?"

Siswa 2 : "Masukkan yang ditanyakan Bu. 5 dikali 11.000 ditambah 2 dikali 10.500 ditambah tiga dikali 6500."

Berdasarkan hasil wawancara, siswa camper menyatakan bahwasannya dalam menuliskan model tersebut tidak mengalami kesulitan. Dari observasi juga, siswa tersebut menjawab dengan yakin arah pemecahan masalah. Berdasarkan hal tersebut, siswa camper memenuhi indikator merencanakan pemecahan masalah.

Pada indikator ketiga yaitu melaksanakan rencana pemecahan, siswa camper dapat menuliskan langkah-langkah penyelesaian. Akan tetapi langkah yang diberikan masih kurang tepat. Siswa camper berhasil menemukan nilai A, B dan C dengan benar. Akan tetapi saat menghitung jenis makanan yang ditambahkan, siswa camper tidak mengerjakannya. Sehingga jawaban yang didapatnya tidak lengkap. Berikut kutipan wawancara siswa camper.

Peneliti : "Hasilnya ketemu berapa?"

Siswa 2 : "Bentar Bu, mau ngitung"

Peneliti : "iya"

Siswa 2 : "95.500, Bu"

Peneliti : "Ini kok jawabannya punyamu 94.500?"

Siswa 2 : "Loh iyatah Bu? Hehe salah ngitung sepertinya, Bu.. hehe"

Berdasarkan wawancara tersebut, siswa tersebut melakukan kesalahan dalam perhitungan. Dari observasi, sisiwa tersebut memang tidak melakukan perhitungan pada jenis makanan yang ditambahkan. Meskipun langkah penyelesaian kurang tepat, karena siswa camper menuliskan langkahnya maka dapat disimpukan bahwa siswa camper memenuhi indikator melaksanakan rencana pemecahan masalah namun kurang lengkap.

Pada indikator memeriksa kembali, siswa camper tidak dapat melakukan pemeriksaan ulang sebagaimana pada Gambar 8.

Peneliti : "Hmm, gak diperiksa ulang ta tadi jawabannya?"

Siswa 2 : "Enggak, hehe"

Alifmatika: Jurnal Pendidikan dan Pembelajaran Matematika, Juni 2020, Vol. 2, No. 1 
Peneliti : "Sama dengan nomor 1 ya.. gak di cek.."

Siswa 2 : "Iya Bu.. saya gak telitian orangnya emang Bu.. Keburuan juga"

Berdasarkan hasil wawancara, siswa camper mengakui kesalahannya tidak memeriksa ulang jawaban dan langkah yang digunakan sehingga siswa camper gagal menemukan jawaban yang benar. Berdasarkan observasi, setelah mengerjakan langkah penyelesaian, siswa camper beranjak ke langkah selanjutnya atau tak memeriksa hasil pekerjaannya. Jadi indikator memeriksa kembali tidak dipenuhi oleh siswa camper.

Berdasarkan tes, observasi dan wawancara pada siswa camper diperoleh hasil pemecahan sebagaimana terangkum dalam Tabel 4 berikut.

Tabel 4. Kemampuan Pemecahan Masalah Siswa Camper

\begin{tabular}{lcccc}
\hline Keterangan & Indikator 1 & Indikator 2 & Indikator 3 & Indikator 4 \\
\hline Nomor 1 & $\sqrt{ }$ & $\sqrt{ }$ & $\sqrt{ }$ & $\times$ \\
Nomor 2 & $\sqrt{ }$ & $\sqrt{ }$ & $\sqrt{ }$ & $\times$ \\
\hline
\end{tabular}

\section{Kemampuan Pemecahan Masalah Quitter}

\section{a. Soal Nomor Satu}

Penyelesaian siswa dan hasil observasi dapat dilihat pada gambar berikut.

$$
\begin{aligned}
& \text { 1. Diket Joxak teanfoin } 146 \mathrm{k} \mathrm{km}\} \text { Memahami Masalah } \\
& \text { Jarak tenipot joto } 9 k \text {. Jemahami } M \\
& \text { Jwb } A+B+C=464 \mathrm{~km} \text { Merencanakan } \\
& c+y=9 \quad \int \begin{array}{l}
\text { Pemecahan } \\
\text { Masalah }
\end{array}
\end{aligned}
$$

Gambar 9. Penyelesaian Quitter Soal Nomor 1

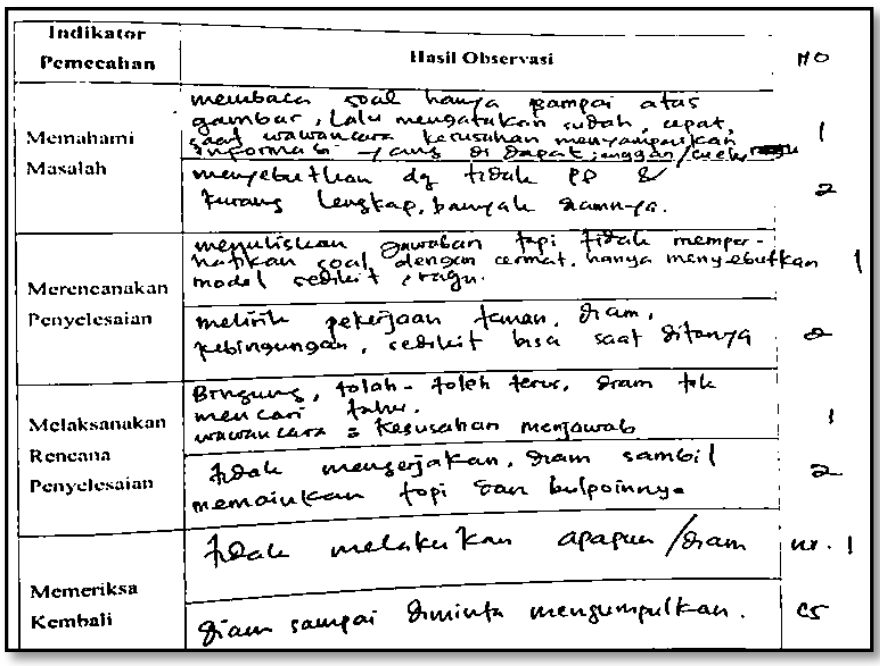

Gambar 10. Hasil Observasi Siswa Quitter 
Berdasarkan Gambar 9, siswa menuliskan apa yang diketahui dari soal namun informasi yang diberikan tidak lengkap. Siswa quitter menuliskan jarak tempuh $464 \mathrm{~km}$, tanpa menyebutkan jarak tempuh siapa yang dimaksud. Kemudian, menuliskan jarak tempuh Joko $9 \mathrm{~km}$, dan pernyataan tersebut kurang tepat. Informasi lain, didapatkan dalam kutipan wawancara berikut.

Peneliti : "Santai.. dah dibaca dulu soalnya"

Siswa 2 : "(membaca)... udah Bu"

Peneliti : "Gimana, udah paham sama soalnya?"

Siswa 2 : "Gaktau Bu lupa"

Peneliti : "Lho.. ayo ayo.. gimana maksud soalnya ituu"

Siswa 2 : "Gak tau Bu.."

Peneliti :"Yang diketahui dan ditanyakan soal apa?"

Siswa 2 : "Jarak tempuh Joko 9 km" (lalu diam)

Peneliti : "Itu belum selesai dek. Belum sampai titik. Jarak tempuh Joko $9 \mathrm{~km}$ lebih jauh dibandingkan jarak tempuh Munir"

Siswa 2 : "Ya.."

Peneliti : "Oke, terus apa lagi yang diketahui?"

Siswa 2 : "Khozin Bu"

Peneliti : "Kenapa Khozin?"

Siswa 2 : "Ini Bu, Khozin, Munir dan Joko 464 km.”

Peneliti : "Terus?"

Siswa 2 : "Udah Bu.."

Peneliti : "Ada lagi dek.. yang ini (menggaris bawahi yang diketahui di soal. Ya..? Udah bisa?"

Siswa 2 : "Ya"

Berdasarkan hasil wawancara, siswa quitter dapat menyebutkan beberapa poin yang diketahui, namun tidak lengkap dan detail. Berdasarkan observasi, disebabkan rasa enggannya untuk berusaha menyelesaikan. Sehingga dapat dikatakan siswa quitter memenuhi indikator memahami masalah meskipun masih kurang.

Pada indikator merencanakan pemecahan masalah, siswa quitter menuliskan dua buah persamaan yakni $A+B+C=464 \mathrm{~km}$ dan $C=9$. Persamaan yang diberikan tersebut kurang lengkap dan kurang benar. Berikut kutipan wawancara dengan siswa quitter.

Peneliti : "Terus gimana ngerjakannya?"

Siswa 3 : "Dihitung"

Peneliti : "Gimana ngitungnya?"

Siswa 3 : "Gimana, Bu"

Peneliti : "Lah iya gimana.. ini materi apa?"

Siswa 3 : "(diam lama) SPLTV, Bu”

Peneliti : "Nah bener, kalo SPLTV biasanya gimana ngerjakannya?" 
Siswa 3 : "Gak tau sama sekali saya Bu"

Peneliti : "Beneran?"

Siswa 3 : "Iya gak tau saya Bu, Ibu tau?"

Peneliti : "Tau lah.."

Siswa 3 : "Kok masih tanya ke saya Bu (sambil ketawa). $A+B+C=464 \mathrm{~km}$ bu"

Peneliti : "Terus?”

Berdasarkan hasil wawancara dan observasi, siswa quitter mengungkapkan sama dengan apa yang dituliskan. Sehingga dapat disimpulkan bahwa siswa quitter memenuhi indikator merencanakan pemecahan namun kurang lengkap.

Pada indikator melaksanakan rencana pemecahan, siswa quitter tidak menuliskan apapun. Berikut kutipan wawancara yang telah dilakukan.

Siswa 3 : "Kok masih tanya ke saya Bu (sambil ketawa). A + B + C = 464 km Bu"

Peneliti : "Terus?"

Siswa 3 : "Gak bisa saya Bu"

Peneliti : "Ayo dek, jawab sebisanya dan sepahammu dah"

Siswa 3 : “(diam) Repot Bu, beneran saya gak bisa sama sekali. Bingung saya $\mathrm{Bu}$ mau nulis apa, Gak tau..”

Peneliti : "Haha.. iya santai dek jangan spaneng.. jangan takut. Iyadah kalo gitu. Nyerah ini dah berarti?"

Siswa 3 : "Nyerah Bu, gak bisa ngerjakannya"

Berdasarkan hasil wawancara, siswa quitter tidak dapat menyebutkan langkah penyelesaian yang akan dilakukan. Siswa quitter hanya terdiam dan sesekali menjawab tidak tahu. Sehingga dapat disimpulkan bahwa siswa quitter tidak dapat memenuhi indikator melaksanakan rencana penyelesaian.

Begitu juga pada tahap memeriksa kembali. Siswa quitter tidak menuliskan dan melakukan apapun. Hal tersebut dikarenakan siswa quitter tidak mengerti apa yang harus ditulis. Meskipun materi SPLTV telah diajarkan, siswa quitter mengaku tidak bisa mengerjakannya. Sehingga pada indikator memeriksa kembali tidak dipenuhi oleh siswa quitter.

\section{b. Soal Nomor Dua}

Penyelesaian siswa quitter dapat dilihat pada gambar berikut.

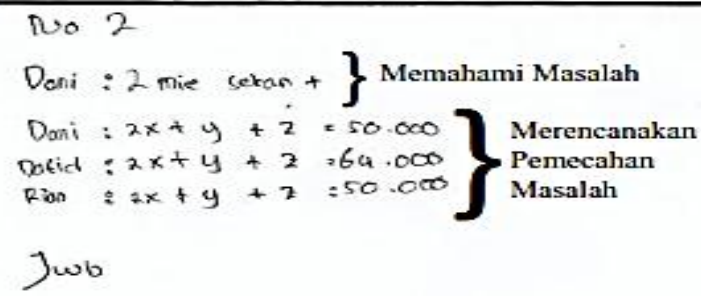

Gambar 11. Penyelesaian Quitter Soal Nomor 2 
Berdasarkan Gambar 9, tidak ditemukan tidak ditemukan pemecahan siswa pada indikator memahami masalah. Siswa quitter langsung menuliskan model matematika dari setiap pihak. Berdasarkan hasil wawancara, siswa quitter mampu memahami maksud dari soal baik yang diketahui dan yang ditanyakan. Namun pemahaman yang dimiliki masih kurang, berikut kutipan wawancara tersebut.

Peneliti : "Gimana maksud soalnya? Paham?"

Siswa 3 : "InsyaAllah. Dani, David Rian beli-beli.. Dani beli 2 mie, 1 siomay sama 1 es 50.000"

Peneliti : "Terus?"

Siswa 3 : "Boh terus? Apalagi bu?"

Peneliti : "Loh yang David sama Rian dan yang ditanyakan"

Siswa 3 : "David membeli seporsi mie setan level 2, tiga porsi siomay dan segelas es tuyul dengan total pembayaran Rp 64.000. Rian membeli seporsi mie setan level 2, seporsi siomay dan segelas es tuyul dengan total pembayaran Rp 50.000”

Karena kurang lengkapnya informasi yang diberikan. Jadi pada indikator memahami masalah, siswa quitter memenuhinya, namun tidak lengkap.

Pada indikator merencanakan penyelesaian masalah, siswa quitter menuliskan model matematika namun masih kurang tepat. Siswa quitter tidak mengurangi total harga dengan ongkos kirim yang ada. Berikut hasil wawancara dengan siswa quitter.

Peneliti : "Terus digimanakan?"

Siswa 3 : "Gak tau Bu"

Peneliti : "Kok gak tau lagi..."

Siswa 3 : "Iya ga ngerti saya Bu"

Peneliti : "Kan belinya pakai grab dek.. berarti ada ongkirnya. Nah nanti harga total itu dikurngi ongkirnya.."

Siswa 3 : "O ya"

Peneliti : "Bisa kalau disuruh ngelanjutkan sendiri?"

Siswa 3 : "Gak bisa Bu, gak usah sudah Bu.."

Peneliti : "Terus tadi ngerjakannya pakai apa?"

Siswa 3 : “(diam)”

Peneliti : "Apa dek?"

Siswa 3 : "Gak tau Bu.. gak ngerjakan saya. Gabisa semua saya Bu"

Peneliti : "Hmm iyadah.. ini gini dek, harga total nanti dikurangi ongkir dulu.. terus dibuat model matematika dek.. di eliminasi substitusi terus.. Setelah itu ketemu nilai $\mathrm{x}, \mathrm{y}$, z nya.. Baru dimasukkan ke yang ditanyakan.. punya Tari.. yaitu $5 x+2 y+3 z$

Siswa 3 : "Oiya Bu"

Peneliti : "Lanjutin ya?"

Siswa 3 : "Ndak Bu.. ga bisa.. mau nulis apa saya" 
Berdasarkan wawancara, siswa quitter tidak begitu paham cara yang harus digunakan. Karena adanya perencanaan yang dilakukan, maka siswa quitter memenuhi indikator perencanaan pemecahan masalah meskipun kurang lengkap.

Pada tahap melaksanakan rencana dan memeriksa kembali, siswa quitter tidak menuliskan apapun. Berdasarkan dari kutipan wawacara berikut.

P0330 : "Bisa kalau disuruh ngelanjutkan sendiri?"

S0330 : "Gak bisa Bu, gak usah sudah Bu.."

P0331 : "Terus tadi ngerjakannya pakai apa?"

S0331 : "(diam)"

P0332 : "Apa dek?"

S0332 : "Gak tau Bu.. gak ngerjakan saya. Gabisa semua saya Bu"

Berdasarkan hasil wawacara, siswa quitter tidak bisa melakukan proses perhitungan sebab tidak bisa dan kesulitan sehingga dapat disimpulkan bahwa siswa quitter tidak berhasil memenuhi indikator melaksanakan rencana pemecahan dan indikator memeriksa kembali.

Berdasarkan hasil tes, observasi dan wawancara pada siswa camper diperoleh hasil pemecahan sebagaimana terangkum dalam Tabel 5 berikut.

Tabel 5. Kemampuan Pemecahan Masalah Siswa Quitter

\begin{tabular}{lcccc}
\hline Keterangan & Indikator 1 & Indikator 2 & Indikator 3 & Indikator 4 \\
\hline Nomor 1 & $\sqrt{ }$ & $\sqrt{ }$ & $\times$ & $\times$ \\
Nomor 2 & $\sqrt{ }$ & $\sqrt{ }$ & $\times$ & $\times$ \\
\hline
\end{tabular}

Indikator pemecahan masalah soal cerita materi SPLTV dicapai berbeda-beda oleh Siswa penelitian. Hal tersebut sejalan dengan penelitian Yuwono et al. (2018) menunjukkan bahwa pada tahap memahami masalah tidak ada kesulitan untuk setiap subjek, pada indikator merencanakan pemecahan ada siswa yang tidak menuliskan perencanaan meskipun memahami, pada indikator melaksanakan rencana penyelesaian ada siswa yang kurang teliti dan tidak memenuhinya dan pada indikator memeriksa kembali terdapat siswa yang tidak mencapainya dikarenakan belum menyelesaikan indikator sebelumnya. Dalam penelitian ini soal cerita dipecahkan oleh Siswa climber maupun camper, namun hasil pemecahan yang diberikan masih kurang tepat. Hal ini selaras dengan penelitian Nuragni (2018) menunjukkan bahwa kemampuan siswa dalam menyelesaikan soal matematika masih rendah.

Siswa climber memenuhi semua indikator pemecahan Polya. Senada dengan hal tersebut, menurut Stoltz (2000) mengatakan bahwa siswa yang memiliki AQ climber cenderung menganggap kesulitan berasal dari luar dirinya, yang merupakan bagian dari hidup. Jadi, menghindari kesulitan sama saja dengan menghindari kehidupan. Kesulitan justru membuatnya menjadi individu yang pantang menyerah. Lebih dari itu, siswa yang memiliki AQ climber selalu merasa tertantang untuk menyelesaikan masalah dan menyelesaikannya dengan gigih, ulet dan penuh keyakinan, termasuk masalah matematika. Sedangkan pemecahan masalah yang dipenuhi oleh camper, senada dengan Stoltz (2000) mengatakan bahwa camper mempunyai ambang kemampuan yang terbatas dalam menghadapi kesulitan, dalam hal ini tidak terlepas juga kesulitan 
memecahkan masalah matematika. Camper memilki keyakinan bahwa setelah melakukan beberapa usaha, hidup seharusnya bebas dari kesusahan, sehingga dalam memecahkan masalah tidak berusaha memecahkannya dengan tuntas. Camper tidak memanfaatkan potensi mereka sepenuhnya, sehingga cenderung kurang berhasil dalam belajar, tumbuh dan berprestasi. Siswa quitter tidak berhasil menemukan jawaban dari kedua soal dikarenakan ketidaktahuannya pada materi dan argumen pribadinya yang menyatakan sulitnya soal. Untuk siswa quitter, menurut ahli psikolog, Stoltz (2000), quitter mempunyai kemampuan yang kecil atau bahkan tidak mempunyai sama sekali. Itulah yang menyebabkan mereka berhenti dalam menemukan solusi soal. Quitter selalu memilih jalan yang mereka anggap lebih datar dan lebih mudah. Jika dihadapkan dengan masalah, quitter akan cenderung melarikan diri secara aktif dari masalah dan mengabaikan potensi yang dimilikinya. Jadi, untuk siswa bertipe quitter, penting sekali untuk aktif dimotivasi agar AQ yang dimilikinya semakin meningkat dan memiliki kemauan yang kuat dalam memecahkan suatu masalah dalam pembelajaran matematika.

\section{KESIMPULAN DAN SARAN}

Siswa bertipe climber mampu memenuhi semua indikator pemecahan masalah pada soal cerita yang meliputi indikator memahami masalah, merencanakan strategi pemecahan masalah, melaksanakan rencana pemecahan dan memeriksa kembali hasil pemecahan masalah. Siswa bertipe camper memenuhi semua indikator pemecahan masalah kecuali pada tahap memeriksa kembali hasil pemecahan masalah. Siswa bertipe quitter dalam menyelesaikan soal cerita memenuhi tahap memahami masalah dan merencanakan strategi pemecahan masalah akan tetapi masih kurang tepat, sedangkan tahap melaksanakan rencana pemecahan masalah dan memeriksa kembali hasil pemecahan masalah tidak dipenuhi oleh siswa quitter. Saran dalam penelitian ini, sebaiknya pendidik lebih sering memberikan motivasi, dorongan dan hal-hal positif lainnya yang dapat meningkatkan Adversity Quotient siswa, sebab dari penelitian ini diketahui bahwa Adversity Quotient yang dimiliki siswa memberikan hasil yang berbeda pada kemampuan pemecahan masalah matematika siswa.

\section{DAFTAR PUSTAKA}

Amanda, L., Yanuar, F., \& Devianto, D. (2019). Uji Validitas dan Reliabilitas Tingkat Partisipasi Politik Masyarakat Kota Padang. Jurnal Matematika UNAND, 8(1), 179-188.

Anggraena, Y. (2019). Pengembangan Kurikulum Matematika untuk Meningkatkan Kemampuan Siswa dalam Penalaran dan Pemecahan Masalah. Alifmatika: Jurnal Pendidikan Dan Pembelajaran Matematika, 1(1), 15-27.

Annizar, A. M., Jakaria, M. H. D., Mukhlis, M., \& Apriyono, F. (2020). Problem solving analysis of rational inequality based on IDEAL model. Journal of Physics: Conference Series, 1465, 12033.

Erviana, T. (2019). Kemampuan Penalaran Matematis Siswa dalam Memecahkan Masalah Aljabar Berdasarkan Gaya Kognitif Field Independent. Alifmatika: Jurnal Pendidikan Dan Pembelajaran Matematika, 1(1), 61-73.

Fathurrahman, M., Permanasari, A., \& Siswaningsih, W. (2016). Pengembangan Tes Keterampilan Problem Solving Siswa SMA pada Pokok Bahasan Stoikiometri 
Larutan. EduChemia (Jurnal Kimia Dan Pendidikan), 1(1), 62-75.

Hendriana, H., \& Soemarmo, U. (2014). Penilaian pembelajaran matematika. Bandung: Refika Aditama.

Huberman, A. M., Miles, M., \& Saldana, J. (2014). Qualitative data analysis: A methods sourcebook. The United States of America: SAGE Publications. Höök, P.(2001). Stridspiloter $i$ Vida Kjolar-Om Ledarutveckling Och Jämställdhet.

Lestanti, M. M., Isnarto, I., \& Supriyono, S. (2016). Analisis Kemampuan Pemecahan Masalah Ditinjau dari Karakteristik Cara Berpikir Siswa dalam Model Problem Based Learning. Unnes Journal of Mathematics Education, 5(1), 16-23.

Maswar, M. (2019). Strategi Pembelajaran Matematika Menyenangkan Siswa (MMS) Berbasis Metode Permainan Mathemagic, Teka-teki Dan Cerita Matematis. Alifmatika: Jurnal Pendidikan Dan Pembelajaran Matematika, 1(1), 28-43. https://doi.org/10.35316/alifmatika.2019.v1i1.28-43

NCTM. (2000). Principle and Standart for School Mathematics. Reston: The National Council of Teacher Mathematics, Inc.

Nuragni, W. T. (2018). Analisis Kemampuan Siswa Dalam Menyelesaikan Soal Matematika Tipe High Order Thinking Pada Pokok Bahasan Pola Bilangan Di Kalangan Siswa Kelas VIII E SMP Negeri 5 Yogyakarta Tahun Ajaran 2018/2019. Skripsi Tidak Diterbitkan. Yogyakarta: Universitas Sanata Dharma.

Rosyidi, A. H. (2005). Analisis Kesalahan Siswa Kelas II MTs Alkhoiriyah dalam Menyelesaikan Soal Cerita yang Terkait dengan Sistem Persamaan Linear Dua Peubah. Tesis yang tidak dipublikasikan. Surabaya: Unesa.

Ruseffendi, E. T. (2005). Dasar-dasar penelitian pendidikan dan bidang non-eksakta lainnya. Bandung: Tarsito.

Stoltz, P. G. (2000). Adversity Quotient: Mengubah Hambatan Menjadi Peluang. Jakarta: Grasindo.

Tohir, M. (2019). Keterampilan Berpikir Kreatif Siswa dalam Menyelesaikan Soal Olimpiade Matematika Berdasarkan Level Metakognisi. Alifmatika: Jurnal Pendidikan Dan Pembelajaran Matematika, 1(1), 1-14. https://doi.org/10.35316/alifmatika.2019.v1i1.1-14

Tok, Ş. (2013). Effects of the know-want-learn strategy on students' mathematics achievement, anxiety and metacognitive skills. Metacognition and Learning, 8(2), $193-212$.

Umar, W. (2016). Strategi Pemecahan Masalah Matematis Versi George Polya Dan Penerapannya Dalam Pembelajaran Matematika. KALAMATIKA Jurnal Pendidikan Matematika, 1(1), 59. https://doi.org/10.22236/kalamatika.vol1no1.2016pp59-70

Yuwono, T., Supanggih, M., \& Ferdiani, R. D. (2018). Analisis Kemampuan Pemecahan Masalah Matematika dalam Menyelesaikan Soal Cerita Berdasarkan Prosedur Polya. Jurnal Tadris Matematika, 1(2), 137-144. https://doi.org/10.21274/jtm.2018.1.2.137-144 